\title{
Phosphorus dynamics of the tropical and subtropical north Atlantic: Trichodesmium spp. versus bulk plankton
}

\author{
Jill A. Sohm*, Douglas G. Capone \\ Department of Biological Sciences and Wrigley Institute for Environmental Studies, University of Southern California, \\ Los Angeles, California 90089, USA
}

\begin{abstract}
Nitrogen fixing organisms such as Trichodesmium spp. are abundant in the oligotrophic tropical North Atlantic Ocean, where microplankton (including other diazotrophs) are more likely to be phosphorus $(\mathrm{P})$ than nitrogen $(\mathrm{N})$ limited. Thus, understanding the ability of different functional groups in the plankton to compete for $\mathrm{P}$ in this area is important for understanding their relative success. The uptake of phosphate by Trichodesmium spp. colonies and bulk water plankton was measured using ${ }^{33} \mathrm{PO}_{4}{ }^{3-}$ over a range of concentrations, and kinetic parameters were determined. Nano- and pico-plankton present in bulk water samples have a $\mathrm{K}_{\mathrm{s}}$ that is nearly 30 times lower than that of Trichodesmium spp. While chl a-normalized alkaline phosphatase activity (APA) in bulk water was an order of magnitude greater than in Trichodesmium spp., Trichodesmium spp. contributes substantially to total APA in the water. Trichodesmium spp. is outcompeted for dissolved inorganic $\mathrm{P}$ (DIP), but colonies can satisfy their P needs by supplementing DIP uptake with P cleaved from dissolved organic P (DOP) via alkaline phosphatase.
\end{abstract}

KEY WORDS: Phosphorus · Phosphate $\cdot$ Nitrogen fixation · Trichodesmium $\cdot$ North Atlantic - Resale or republication not permitted without written consent of the publisher

\section{INTRODUCTION}

Phosphorus (P) has a very long residence time in the oceans (Codispoti 1989), even though estimates have been recently revised downwards due to new analyses (Benitez-Nelson 2000). The cycling of this macronutrient has long been viewed as primarily controlled by chemical processes occurring on geological time scales, with the conversions that happen in the biological realm being incidental (Tyrell 1999, BenitezNelson 2000). This stems from the common view that biological productivity of the world's oceans is primarily nitrogen $(\mathrm{N})$ limited, with changes in $\mathrm{P}$ cycling (Benitez-Nelson 2000) or $\mathrm{N}$ inventories being tempered through the regulation of nitrogen fixation and denitrification (Michaels et al. 2001). However, certain areas of the globe are now thought to be P limited (e.g. the Mediterranean, Thingstad et al. 2005); thus the study of $\mathrm{P}$ dynamics in these areas is essential.
Trichodesmium spp. is a nitrogen fixing, colony forming cyanobacteria that occurs in many areas of the ocean where warm, calm waters and oligotrophic conditions prevail (Capone et al. 1997). Colonies can take on either the tuft formation (parallel alignment of trichomes) or the puff formation (radially arranged trichomes). The diazotrophic nature of Trichodesmium spp. ensures that it is never limited by $\mathrm{N}$, and thus other nutrients are important in regulating growth and nitrogen fixation. Both $\mathrm{P}$ and Fe have been suggested as limiting to diazotrophs, but it appears most likely that different nutrients may limit nitrogen fixers in different areas of the ocean. High concentrations of $\mathrm{Fe}$ from large fluxes of dust from the African continent (Wu et al. 2000) and high densities of nitrogen fixing organisms such as Trichodesmium spp. (Carpenter et al. 2004, Capone et al. 2005) create conditions conducive to $\mathrm{P}$ limitation in the tropical and subtropical North Atlantic (Wu et al. 2000, Sañudo- 
Wilhelmy et al. 2001). Studies show that both the bulk water plankton (made up in large part by heterotrophic bacteria and the cyanobacteria Prochlorococcus spp. and Synechococcus spp. [Li et al. 1992]) and Trichodesmium spp. are P limited in the North Atlantic (Cotner et al. 1997, Sañudo-Wilhelmy et al. 2001, Ammerman et al. 2003, Krauk et al. 2006). The apparent limitation by $\mathrm{P}$ of these various groups means that they must compete with each other for $\mathrm{P}$ from both the dissolved inorganic (DIP) and organic (DOP) pools. Both picoplankton and Trichodesmium spp. can access the DIP and DOP pools of P through P transport enzymes and alkaline phosphatase. In addition, basic local alignment search tool (BLAST) searches have found sequences in the genome of Trichodesmium erythraeum IMS 101 for phosphonate transport and metabolism proteins, indicating that Trichodesmium spp. may be able to exploit this often overlooked component of DOP (genome.ornl.gov/ microbial/tery, Dyhrman et al. 2006).

How, exactly, a Trichodesmium spp. colony is able to acquire enough $\mathrm{P}$ to fulfill its cellular requirements when it grows in areas with such low $\mathrm{PO}_{4}{ }^{3-}$ concentrations has been an issue of debate for years, with some suggesting that colonies might migrate towards the phosphocline when P-depleted to take up large amounts of $\mathrm{P}$ and then return to the surface (Karl et al. 1992). However, if Trichodesmium spp. can successfully compete for either DIP or DOP, it may be able to acquire the necessary $\mathrm{P}$ for growth without migration to the phosphocline.

To assess the ability of Trichodesmium spp. to compete with bulk plankton for $\mathrm{P}$ in a $\mathrm{P}$ limited system, we measured $\mathrm{PO}_{4}{ }^{3-}$ uptake kinetics and alkaline phosphatase activity for both sample types in the subtropical and tropical western North Atlantic in March 2004.

\section{MATERIALS AND METHODS}

Sample collection. Experiments were performed aboard the RV 'Endeavor' in March 2004 on a southeast transect from about $30^{\circ} \mathrm{N}, 65^{\circ} \mathrm{W}$ down to $10^{\circ} \mathrm{N}$, $50^{\circ} \mathrm{W}$ (Fig. 1). Samples were collected by towing a $0.25 \mathrm{~m}, 202 \mathrm{~mm}$ mesh net at a depth of 15 to $20 \mathrm{~m}$ for about $10 \mathrm{~min}$ at a time. Colonies were found in both the puff and tuft formations, with puffs outnumbering tufts. Colonies were picked out of the tow sample using a plastic inoculating loop and placed into filtered seawater to rinse. The colonies were then picked out of the rinse and placed in bottles used for different assays. Efforts were made to place the different colony conformations into assays at approximately the same abundance that they were found in the tow. Colonies were not obtained at all stations, particularly those at

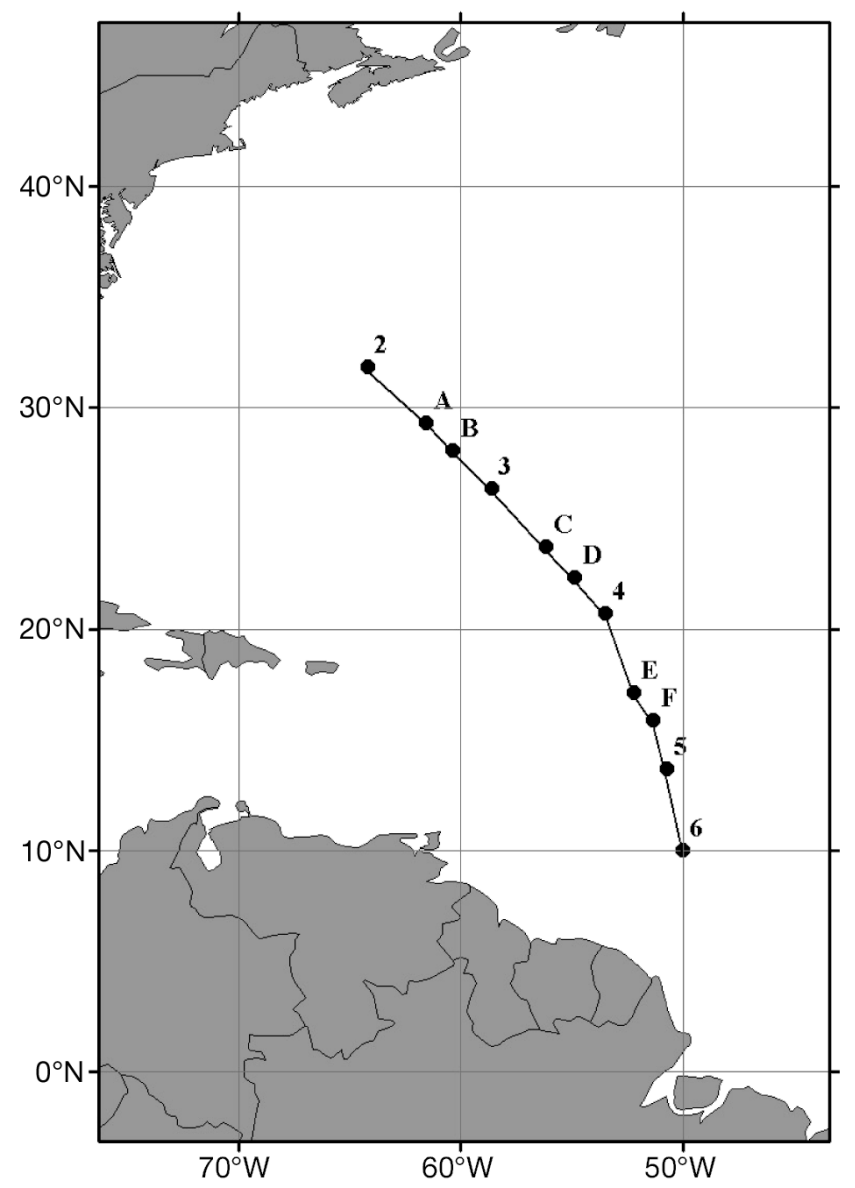

Fig. 1. Station locations in the subtropical and tropical North Atlantic

the northern end of the transect. Bulk plankton was collected from either a clean underway seawater system or from near the surface $(<2 \mathrm{~m}$ depth) sampled by a Niskin bottle on a CTD rosette system.

$\mathbf{P O}_{4}{ }^{3-}$ uptake. Samples $(50 \mathrm{ml})$ of bulk seawater or filtered seawater containing 10 Trichodesmium spp. colonies were placed in $60 \mathrm{ml}$ acid washed polycarbonate bottles with 0.5 to $2 \mu \mathrm{Ci}$ of ${ }^{33} \mathrm{PO}_{4}{ }^{3-}$ and incubated in $25 \%$ light on deck incubators for 60 to $90 \mathrm{~min}$. Incubations were filtered onto polycarbonate filters, $8 \mu \mathrm{m}$ for Trichodesmium spp. colonies and $0.2 \mu \mathrm{m}$ for bulk seawater samples. Incubation bottles were rinsed 3 times with $0.2 \mu \mathrm{m}$ filtered seawater, the rinse poured over the filters, with one final filtered seawater rinse of the filter towers before the filters were placed into $7 \mathrm{ml}$ plastic scintillation vials. Activity of ${ }^{33} \mathrm{P}$ was measured on board in a scintillation counter after addition of $5 \mathrm{ml}$ scintillation cocktail. Experiments conducted on this cruise and on previous cruises that showed DIP uptake in Trichodesmium spp. is linear for the first 60 to 90 min. Other studies have shown that DIP uptake in bulk samples of seawater is linear for many hours (Björkman et al. 2000). 
The Michaelis-Menten equation is used to describe the uptake kinetics of nutrients. By fitting the equation $\mathrm{V}=\mathrm{V}_{\max } \times \mathrm{S}\left(\mathrm{K}_{\mathrm{s}}+\mathrm{S}\right)^{-1}$ to a plot of $\mathrm{PO}_{4}{ }^{3-}$ concentration (S) in an incubation versus the $\mathrm{PO}_{4}{ }^{3-}$ uptake rate (V) at that concentration, one can solve for the rate of maximal uptake $\left(\mathrm{V}_{\max }\right)$ and the half saturation constant $\left(\mathrm{K}_{\mathrm{s}}\right)$. To create kinetic curves, 0 to $1 \mu \mathrm{M}$ of cold $\mathrm{PO}_{4}{ }^{3-}$ was added to incubations, followed immediately by radiolabeled $\mathrm{PO}_{4}{ }^{3-}$ addition. Samples were then treated as described above. SigmaPlot was used to directly fit the Michaelis-Menten equation to the data and extract $V_{\max }$ and $K_{\mathrm{s}}\left(\mathrm{K}_{\mathrm{s}}\right.$ was corrected for the amount of DIP measured in surface water). It has been recently shown that a significant amount of phosphorus in a colony is sorbed to the outside of the cells, and washing sorbed $\mathrm{P}$ from the outside of the cells is important when measuring actual $\mathrm{P}$ uptake with ${ }^{33} \mathrm{PO}_{4}{ }^{3-}$ (Sañudo-Wilhelmy et al. 2004). To control for this abiological adsorption of phosphorus, a killed control was always conducted with addition of $1 \mathrm{ml}$ of glutaraldehyde to measure abiological adsorption to colonies, and calculations for P uptake were corrected for this. Uptake of the radioisotope in killed controls of Trichodesmium spp. was $8 \%$ (on average) of the uptake of ${ }^{33} \mathrm{P}$ into live colonies.

Alkaline phosphatase activity. The $\mathrm{PO}_{4}{ }^{3-}$ moiety is cleaved from DOP at the cell surface and taken up as inorganic $\mathrm{PO}_{4}{ }^{3-}$, and thus will not be accounted for in measurements of $\mathrm{PO}_{4}{ }^{3-}$ uptake with respect to ambient $\mathrm{PO}_{4}{ }^{3-}$ concentration. It is therefore important to measure the activity of alkaline phosphatase separate from $\mathrm{PO}_{4}{ }^{3-}$ uptake to assess the potential for uptake of phosphate from the DOP pool.

The method described by Ammerman (1993) was used to measure APA. Briefly, $250 \mathrm{ml}$ samples of surface seawater or 30 colonies of Trichodesmium spp. in unfiltered surface seawater were incubated with $100 \mathrm{nM}$ methylumberiferone (MUF-P). Alkaline phosphatase cleaves the $\mathrm{PO}_{4}{ }^{3-}$ moiety from the molecule, causing it to fluoresce. Samples were incubated in on-deck incubators at $25 \%$ light and the increase in fluorescence of MUF was measured over the course of the day, usually over a 6 to $7 \mathrm{~h}$ period, using a Turner 10-AU fluorometer with a long WL oil lab filter kit. APA was calculated using the linear portion of the slope of MUF fluorescence versus time, relative to a $100 \mathrm{nM}$ MUF standard, and the concentration of DOP in the water. For assays on Trichodesmium spp., the rate of APA measured in seawater was subtracted from the activity of Trichodesmium spp. plus surface seawater to obtain activity of Trichodesmium spp. alone. Experiments were conducted in this manner because in previous experiments, we have seen that filtering seawater can increase activity relative to unfiltered water, possibly due to cell breakage and release of the phosphatase enzyme.
Chl $a$ and nutrient analyses. Chl a concentrations were determined by filtering $1 \mathrm{l}$ of seawater onto a GF/F glass fiber filter, extracting the chlorophyll with acetone for $24 \mathrm{~h}$, then reading the sample on a fluorometer set to detect chl $a$ and comparing it to a known standard. Chlorophyll from colonies of Trichodesmium spp. was also extracted in acetone and measured on a fluorometer after $24 \mathrm{~h}$. Surface samples for DIP concentration were collected in acid washed plastic vials and measured with the MAGIC method (Karl \& Tien 1992). Samples were concentrated by a factor of 6 , making the limit of detection $5 \mathrm{nM}$. Total dissolved phosphorus (TDP) was measured on unfiltered samples (as PP was assumed to be $<10 \%$ of total P) using the high temperature combustion and acid hydrolysis method of Solorzano \& Sharp (1980). DOP was calculated by subtracting DIP from TDP.

\section{RESULTS}

DIP and DOP concentrations in this area of the North Atlantic Ocean were found to be very low at this time of year, with DIP averaging $0.04 \mu \mathrm{M}$, while DOP concentrations were almost an order of magnitude higher at $0.11 \mu \mathrm{M}$ (Table 1). Chl a showed about a 10 -fold range of concentrations along the transect, from 0.018 to $0.22 \mu \mathrm{g} \mathrm{l}^{-1}$, whereas Trichodesmium spp. chl a content was 8 to $27 \mu \mathrm{g}$ colony ${ }^{-1}$.

Chl a-normalized APA in bulk water was similar among most stations. However, Stn 3 showed an extreme rate of $83.9 \mathrm{nmol} \mathrm{P} \mathrm{mg} \mathrm{chl} \mathrm{a}^{-1} \mathrm{~h}^{-1}$, much higher than at the other stations. On average, bulk water APA was $19.4 \pm 32.1 \mathrm{nmol} \mathrm{P} \mu \mathrm{g} \mathrm{chl} \mathrm{a}^{-1} \mathrm{~h}^{-1}$. APA for Trichodesmium spp. was measured at 3 stations, and the activity measured averaged $5.9 \pm 3.8 \mathrm{nmol} \mathrm{P} \mu \mathrm{g} \mathrm{chl} \mathrm{a}^{-1}$ $\mathrm{h}^{-1}$. When comparing average Trichodesmium spp. APA to bulk water APA, chl a-specific bulk water APA was 4 times greater than that of Trichodesmium spp. over the entire region studied. However, if the high value from Stn 3 is removed, they are nearly the same.

The chl a-normalized uptake of $\mathrm{PO}_{4}{ }^{3-}$ at ambient concentrations in bulk water samples measured with ${ }^{33} \mathrm{P}$ was nearly a factor of 3 greater than uptake from the DOP pool (as measured from APA), while DIP uptake in Trichodesmium spp. was an order of magnitude less than APA.

Phosphate uptake kinetic curves were determined for bulk water at 2 stations (B and C) and Trichodesmium spp. at 2 stations (5 and 6), with 2 curves produced at Stn 6. An example of each can be seen in Fig. 2. $\mathrm{V}_{\max }$ averaged $12.2 \pm 2.1 \mathrm{nmol} \mathrm{P} \mu \mathrm{g} \mathrm{chl} a^{-1} \mathrm{~h}^{-1}$ for bulk samples and $10.3 \pm 4.7 \mathrm{nmol} \mathrm{P} \mu \mathrm{g}$ chl $\mathrm{a}^{-1} \mathrm{~h}^{-1}$ for Trichodesmium spp. (Table 2). $\mathrm{K}_{\mathrm{s}}$ of bulk plankton was $0.015 \mu \mathrm{M}$ at both stations where it was measured, while 
Table 1. Concentrations of chl $a$, DIP and DOP in the North Atlantic Ocean and DIP uptake and alkaline phosphatase activity (APA) of bulk water samples and Trichodesmium spp. colonies at ambient DIP and DOP concentrations. At Stn 6, bulk water and Trichodesmium spp. $\mathrm{PO}_{4}{ }^{3-}$ uptake rates were determined twice. Tricho: Trichodesmium spp.

\begin{tabular}{|c|c|c|c|c|c|c|c|c|}
\hline Stn & $\begin{array}{l}\text { DIP } \\
(\mu \mathrm{M})\end{array}$ & $\begin{array}{l}\text { DOP } \\
(\mu \mathrm{M})\end{array}$ & $\begin{array}{l}\text { Bulk chl a } \\
\quad\left(\mu \mathrm{g} \mathrm{l}^{-1}\right)\end{array}$ & $\begin{array}{l}\text { Tricho chl a } \\
\left(\mu \mathrm{g} \text { colony }^{-1}\right)\end{array}$ & $\begin{array}{l}\text { Bulk APA } \\
(\mathrm{nmol} P \mu g \\
\left.\mathrm{chl} a^{-1} \mathrm{~h}^{-1}\right)\end{array}$ & $\begin{array}{l}\text { Tricho APA } \\
(\mathrm{nmol} \mathrm{P} \mu \mathrm{g} \\
\left.\mathrm{chl} a^{-1} \mathrm{~h}^{-1}\right)\end{array}$ & $\begin{array}{c}\text { Bulk } \mathrm{PO}_{4} \text { uptake } \\
\text { (nmol } \mathrm{P} \mu \mathrm{g} \\
\left.\text { chl } a^{-1} \mathrm{~h}^{-1}\right)\end{array}$ & $\begin{array}{c}\text { Tricho } \mathrm{PO}_{4} \text { uptake } \\
\text { (nmol } \mathrm{P} \mu \mathrm{g} \\
\text { chl } a^{-1} \mathrm{~h}^{-1} \text { ) }\end{array}$ \\
\hline 2 & 0.05 & 0.17 & 0.121 & & 17.6 & & 25.0 & \\
\hline $\mathrm{A}$ & 0.01 & 0.18 & 0.22 & & 1.5 & & 2.8 & \\
\hline $\mathrm{B}$ & 0.02 & 0.09 & 0.21 & & & & 7.1 & \\
\hline 3 & 0.02 & & 0.018 & 0.015 & 83.9 & & 61.1 & 0.02 \\
\hline $\mathrm{C}$ & 0.01 & 0.06 & 0.026 & & 3.9 & & 53.8 & \\
\hline $\mathrm{D}$ & 0.01 & 0.07 & 0.035 & & & & 48.6 & \\
\hline 4 & 0.08 & & & 0.027 & & 4.5 & & 0.51 \\
\hline E & 0.04 & 0.10 & 0.051 & & 6.5 & & 154.9 & \\
\hline $\mathrm{F}$ & 0.03 & 0.12 & 0.039 & & & & 74.4 & \\
\hline 5 & 0.06 & & & 0.019 & & 3.1 & & 0.27 \\
\hline 6 & 0.07 & & 0.128 & $0.008 / 0.008$ & 3.1 & 10.3 & $69.5 / 43.8$ & $1.03 / 0.62$ \\
\hline Average & 0.04 & 0.11 & 0.16 & 0.015 & 19.4 & 5.9 & 54.1 & 0.53 \\
\hline
\end{tabular}
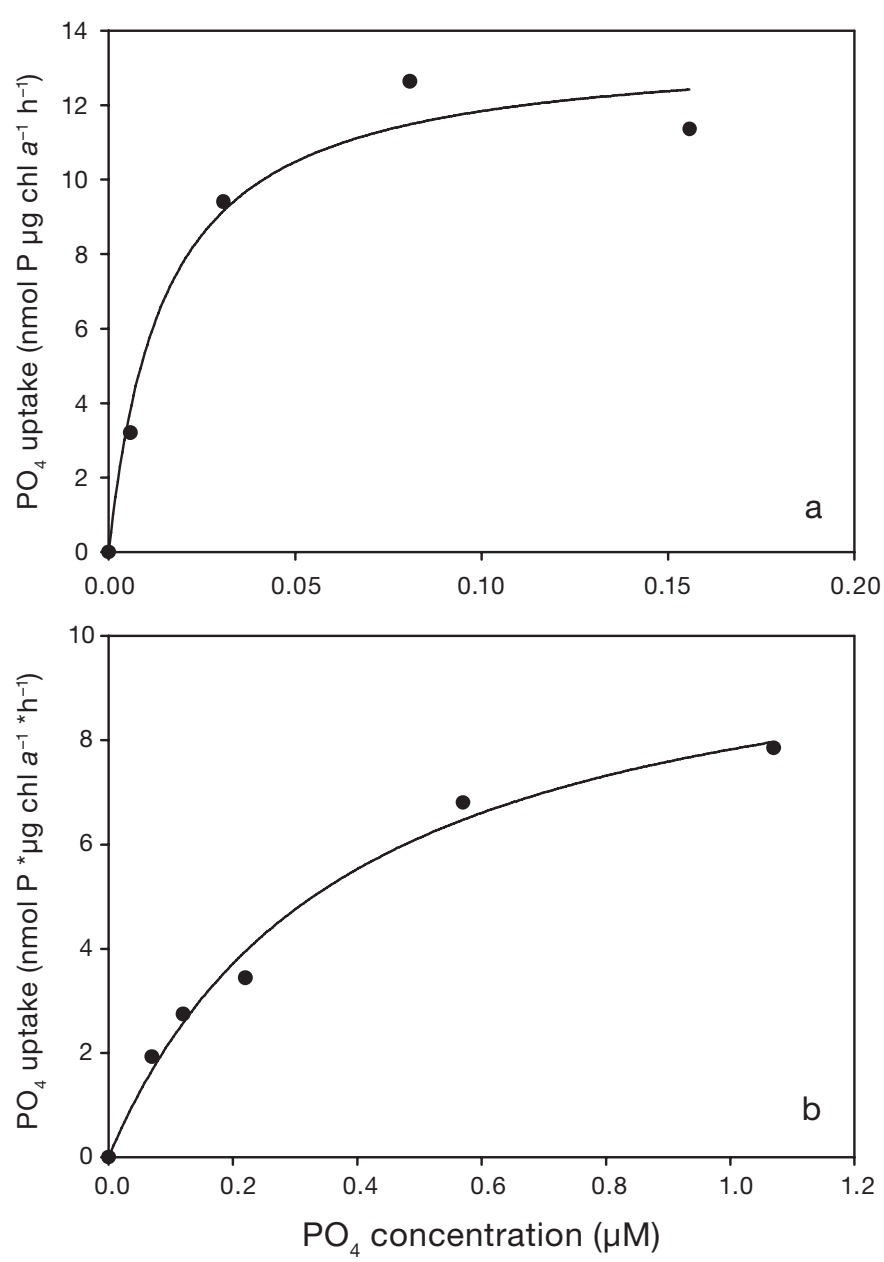

Fig. 2. Examples of kinetic curves for (a) bulk water samples (Stn B) and (b) Trichodesmium spp. colonies (Stn 6). $\mathrm{PO}_{4}{ }^{3-}$ concentration represents amount of cold $\mathrm{PO}_{4}{ }^{3-}$ added to incubations plus ambient $\mathrm{PO}_{4}{ }^{3-}$ concentration in surface water. Note different scales on $x$ - and $y$-axes
$\mathrm{K}_{\mathrm{s}}$ of Trichodesmium spp. was $0.78 \pm 0.37 \mu \mathrm{M}$ on average, 50 times greater than that of bulk plankton (Table 2). The affinity of bulk plankton and Trichodesmium spp. for $\mathrm{PO}_{4}{ }^{3-}$ can be calculated as $\mathrm{V}_{\max } \times \mathrm{K}_{\mathrm{s}}{ }^{-1}$ (also known as a), and was 0.81 and $0.0161 \mu \mathrm{g} \mathrm{chl} a^{-1} \mathrm{~h}^{-1}$, respectively.

\section{DISCUSSION}

Based on previous studies (Cotner et al. 1997, Rivkin \& Anderson 1997, Obernosterer et al. 2003) and rapid $\mathrm{PO}_{4}{ }^{3-}$ pool turnover times of about $10 \mathrm{~h}$ in the surface waters measured during our cruise in March 2004 (data not shown), the area in the western North Atlantic from $30^{\circ}$ to $10^{\circ} \mathrm{N}$ appears to be strongly P limited. The relatively high surface concentrations of $\mathrm{Fe}(\mathrm{Wu}$ et al. 2001), comparisons of nitrogen fixation rates with colony P content (Sañudo-Wilhelmy et al. 2001) and particulate N:P ratios that are very high (Krauk et al. 2006), have led others to conclude that $P$ exerts a major control on Trichodesmium spp. growth specifically, and diazotroph growth in general, in the tropical and subtropical North Atlantic. Dyhrman et al. (2002) also concluded that Trichodesmium spp. colonies in this region are severely $\mathrm{P}$ stressed, by using an ELF assay that visualizes P-stressed trichomes. Our results from Trichodesmium spp. populations in this area also point to $\mathrm{P}$ limitation. $\mathrm{V}_{\max }$ values are 11 and 7 times greater than those found in the North Pacific Subtropical Gyre and off the north coast of Australia (J. A. Sohm et al. unpubl. data), areas that may be less P limited than the North Atlantic. Thus, competition for phosphorus among the planktonic organisms in the North Atlantic may be a defining feature of this ecosystem. 
Table 2. $\mathrm{V}_{\max }, \mathrm{K}_{\mathrm{s}}$, and $\alpha$ for bulk water and Trichorichodesmium spp. samples (values determined twice at Stn 6). Parameters found by fitting the Michaelis-Menten equation to data. $\alpha: \mathrm{V}_{\max } \times \mathrm{K}_{\mathrm{s}}^{-1}$

\begin{tabular}{|lccc|}
\hline Stn & $\begin{array}{c}\mathrm{V}_{\max } \\
(\mathrm{nmol} \mathrm{P}\end{array}$ & $\begin{array}{c}\mathrm{K}_{\mathrm{s}} \\
(\mu \mathrm{M})\end{array}$ & $\begin{array}{c}\alpha \\
\left(\mathrm{l} \mu \mathrm{g} \mathrm{chl} \mathrm{c}^{-1}\right. \\
\left.\mathrm{h}^{-1}\right)\end{array}$ \\
\hline Bulk $\left.\mathrm{a}^{-1} \mathrm{~h}^{-1}\right)$ & & \\
B & & & \\
C & 13.6 & 0.015 & 0.91 \\
Trichodesmium spp. & 10.7 & 0.015 & 0.71 \\
5 & 5.5 & & \\
6 & 10.8 & 0.85 & 0.006 \\
6 & 14.8 & 0.38 & 0.028 \\
\hline
\end{tabular}

Chl a-normalized uptake rates of DIP and alkaline phosphatase activity were both higher in bulk plankton than in Trichodesmium spp., as was the calculated $\mathrm{V}_{\text {max }}$. It is important to recognize that a portion of the activities measured in bulk samples are carried out by heterotrophic bacteria, and thus that these organisms are not represented in the chl a measurements. This problem can be overcome by estimating volumetric rates (Table 3), and it can be seen that the patterns still hold.

While there are measurements of P uptake and APA in different areas of the Atlantic for either bulk water plankton or Trichodesmium spp., ours is the first study to directly compare these enzyme activities in both bulk samples of water and Trichodesmium spp. Donald et al. (2001) measured P uptake by bulk plankton along a transect at $20^{\circ} \mathrm{W}$ between $57.5^{\circ}$ and $37^{\circ} \mathrm{N}$, and found rates of 0.42 to $1.7 \mathrm{nM} \mathrm{h}^{-1}$, which are comparable to but less than the average volumetric $\mathrm{P}$ uptake found in our study of $4.8 \mathrm{nM} \mathrm{h}^{-1}$ (Table 3). Maximal $\mathrm{PO}_{4}$ uptake found at stations in the Sargasso Sea near Bermuda was $0.78 \mathrm{nM} \mathrm{h}^{-1}$ in August and $0.82 \mathrm{nM} \mathrm{h}^{-1}$ in March (Cotner et al. 1997), less than the ambient uptake rates found in our study. However, $\mathrm{P}$ uptake in our study was generally lower at the more northern stations where Cotner et al. (1997) collected their data, and comparable to the rates found in their study. Maximal alkaline phosphatase activity found in the same study was $1.39 \mathrm{nM} \mathrm{h}^{-1}$ in August and $2.7 \mathrm{nM} \mathrm{h}^{-1}$ in March. While this is higher on average than the rates that we found $\left(0.65 \mathrm{nM} \mathrm{h}^{-1}\right)$, the APA observed at the Bermuda Atlantic Time Series station (near where the Cotner et al. [1997] data was collected) was $2.13 \mathrm{nM} \mathrm{h}^{-1}$, which is in line with results from Cotner et al. (1997).

Trichodesmium spp. APA observed in the present study is within the range of activities found for Trichodesmium spp. in waters north of Australia (0.65 to 13.1 nmol P $\mu \mathrm{g} \mathrm{chl} a^{-1} \mathrm{~h}^{-1}$ ), a location that has much higher concentrations of DOP than found in this study (Mulholland et al. 2002). APA reported for Trichodesmium spp. in the southwest North Atlantic in late May was found to range from 0.03 to $0.24 \mu \mathrm{mol}$ MUF-P hydrolyzed $\mu \mathrm{g}$ chl $a^{-1} \mathrm{~h}^{-1}$ (Mulholland et al. 2002), which was 1 to 2 orders of magnitude higher than the rates found in our study. Another study of Trichodesmium spp. APA in the Red Sea, which used the substrate $p$-nitrophenylphosphate, found activities of 2.4 to $11.7 \mu \mathrm{mol} p$-nitrophenylphosphate hydrolyzed $\mu \mathrm{g} \mathrm{chl}$ $a^{-1} h^{-1}$ (Stihl et al. 2001). However, this data represents maximal uptake rates, as saturating substrate concentrations were added and the experiments were conducted at $37^{\circ} \mathrm{C}$. While these rates are not directly comparable, they suggest that Trichodesmium spp. in the western tropical Atlantic near the Caribbean and possibly in the Red Sea are substantially more P-stressed than colonies observed in our study.

Only 1 study to date has measured both DIP and DOP dynamics in Trichodesmium spp., and this data set is limited. McCarthy \& Carpenter (1979) measured $\mathrm{PO}_{4}{ }^{3-}$ uptake kinetics of Trichodesmium spp. at 1 station in the Central Atlantic at $30^{\circ} \mathrm{N}$ and APA at 2 stations on the same transect. This early work demonstrated the ability of Trichodesmium spp. to gain a large part of its phosphorus quota from the DOP pool. APA obtained from 2 experiments, measured using the 3-0 methylumbelliferyl phosphate method, was 2 orders of magnitude higher (170 and $300 \mathrm{nmol} P \mu \mathrm{g}$ chl $a^{-1} \mathrm{~h}^{-1}$ ) than found in the present study. The $\mathrm{K}_{\mathrm{s}}$ reported for Trichodesmium spp. $(9 \mu \mathrm{M})$ was far greater than observed in our study. A subsequent

Table 3. Average volumetric rates of DIP uptake and APA for bulk plankton and Trichodesmium spp., assuming 1 colony $\mathrm{l}^{-1}$ (Carpenter et al. 2004), and percentage of total uptake or activity for which either group is responsible

\begin{tabular}{|lcccc|}
\hline & $\begin{array}{c}\text { DIP uptake } \\
\left(\mathrm{nM} \mathrm{h}^{-1}\right)\end{array}$ & $\begin{array}{c}\text { APA } \\
\left(\mathrm{nM} \mathrm{h}^{-1}\right)\end{array}$ & $\begin{array}{c}15 \% \mathrm{APA}^{\mathrm{a}} \\
\left(\mathrm{nM} \mathrm{h}^{-1}\right)\end{array}$ & $\begin{array}{c}\text { \% of total } \\
\text { DIP uptake }\end{array}$ \\
\hline Bulk plankton & $4.8 \pm 4.2$ & $0.65 \pm 0.74$ & 0.10 & 99.9 \\
Trichodesmium spp. & $0.0067 \pm 0.0042$ & $0.076 \pm 0.028$ & 0.011 & 0.1 \\
a Column shows APA if only 15\% of DOP is bioavailable, the upper limit found by Björkman \& Karl (2003) \\
\hline
\end{tabular}


study of P uptake in exponentially growing batch cultures of Trichodesmium spp. isolated from the North Atlantic found a much lower $\mathrm{K}_{\mathrm{s}}$ value of about $0.4 \mu \mathrm{M}$ for both P replete and P deplete cells (Fu et al. 2005), very similar to the values found in our study. The doubling time for Trichodesmium spp. colonies in the North Atlantic based on $\mathrm{PO}_{4}{ }^{3-}$ uptake alone was 5000 h, or 208 d (McCarthy \& Carpenter 1979). A recent publication contends that this doubling time was too large by 3 orders of magnitude (Moutin et al. 2005). Close inspection does show that the $\mathrm{PO}_{4}{ }^{-3}$ uptake values reported in the text (used to calculate the doubling time) differ by 3 orders of magnitude from the graph of $\mathrm{PO}_{4}{ }^{3-}$ uptake kinetics. However, McCarthy \& Carpenter (1979) became aware of this discrepancy soon after it was published, and state that the original values reported in the text are correct, while a symbol was misprinted on the $y$-axis of the graph of this data (J. McCarthy pers. comm.). Therefore, their results on the importance of DOP for Trichodesmium spp. should still be considered relevant.

Based on the $K_{\mathrm{s}}$ and affinity $(\alpha)$ values found in our study, Trichodesmium spp. cannot effectively compete for phosphate with smaller planktonic organisms in the upper water column. It does, however, have high rates of APA compared to DIP uptake. Thus we surmise that the DOP pool is very important to Trichodesmium spp. with respect to $\mathrm{P}$ acquisition, while for the nano- and picoplankton in the water, it may be merely a supplement. Very similar results were found in the central Baltic Sea where the heterocycstous cyanobacteria Nodularia spumigena and Aphanizomenon sp. occur (Nausch et al. 2004). In this area, when P limitation occurred in mid-summer, $91 \%$ of $\mathrm{PO}_{4}{ }^{3-}$ uptake was carried out by the smallest size fractions $(0.2$ to $3 \mu \mathrm{m})$ while the $>10 \mu \mathrm{m}$ fraction, which included large amounts of cyanobacteria, was responsible for $42 \%$ of APA, indicating that DOP is a much greater source of $\mathrm{P}$ to heterocystous cyanobacteria in the Baltic Sea than DIP (Nausch et al. 2004). The importance of the DOP pool to Trichodesmium spp. was alluded to in a study of Trichodesmium spp. ultrastructure in sinking and rising colonies in the Caribbean (Romans et al. 1994). Sinking colonies were found at $25 \mathrm{~m}$ (a depth of low $\mathrm{PO}_{4}{ }^{3-}$ concentrations) with large inclusions of polyphosphate. Presumably, Trichodesmium spp. would have had to access the DOP pool to accumulate these large amounts of intracellular P (Romans et al. 1994).

However, a very different result was obtained in a recent study on $\mathrm{PO}_{4}{ }^{3-}$ uptake by Trichodesmium spp. in the South Pacific, near New Caledonia (Moutin et al. 2005). From P-specific $\mathrm{PO}_{4}{ }^{3-}$ uptake data, the authors calculated that Trichodesmium spp. could achieve a growth rate of $0.1 \mathrm{~d}^{-1}$ at a $\mathrm{PO}_{4}{ }^{3-}$ concentration of $9 \mathrm{nM}$. Thus, Trichodesmium spp. could coexist with smaller plankton by growing slowly and using only DIP (Moutin et al. 2005). Our data show a very different result. Assuming a colony $\mathrm{P}$ quota of $3.9 \mathrm{nmol}$ (Carpenter 1983), $\mathrm{PO}_{4}{ }^{3-}$ concentrations would have to be $0.15 \mu \mathrm{M}$ to achieve a $0.1 \mathrm{~d}^{-1}$ growth rate, higher than DIP concentrations found in surface waters. Thus, in the subtropical and tropical North Atlantic, where our study was carried out, Trichodesmium spp. does not appear to be able to grow on DIP alone. Uptake of P from the DOP pool appears very important to growth.

It is important to consider that APA derived from the MUF-P method does not take into account the bioavailability of the DOP pool. Björkman \& Karl (2003) estimate that 7 to $15 \%$ of DOP in the North Pacific is available to organisms. If a DOP bioavailability of $15 \%$ is assumed, the importance of DOP as a P source to Trichodesmium spp. is reduced (Table 3), but would still account for over $60 \%$ of $\mathrm{P}$ acquisition. DOP availability of $15 \%$ reduces the contribution of DOP in bulk plankton to a very low $2 \%$.

To assess the volumetric contribution of Trichodesmium spp. to total uptake from the DIP and DOP pools, we assumed colony density in this area to be 1 colony $\mathrm{l}^{-1}$ (Carpenter et al. 2004) to evaluate what percentage of $\mathrm{P}$ from each pool might be incorporated into Trichodesmium spp. This was calculated by dividing ambient $\mathrm{PO}_{4}{ }^{3-}$ uptake or APA of Trichodesmium spp. by the sum of Trichodesmium spp. and bulk seawater $\mathrm{PO}_{4}{ }^{3-}$ uptake or APA. While virtually none of the DIP would be taken up by Trichodesmium spp. (0.1\%), Trichodesmium spp. could be responsible for nearly $11 \%$ of the total uptake of DOP (Table 3). Therefore, Trichodesmium spp. contributes considerably to the turnover of the DOP pool, while the turnover of the DIP pool is carried out almost entirely by smaller organisms in the water. This is in agreement with measurements of size-fractionated P uptake in the Atlantic. In the northeastern Atlantic it was found that the smallest size fraction, 0.2 to $2 \mu \mathrm{m}$, was responsible for the bulk of the $\mathrm{PO}_{4}{ }^{3-}$ uptake (58 to $88 \%$, Donald et al. 2001). For a wide area of the central Atlantic, P uptake was also found to be greatest for the smallest organisms (Cañellas et al. 2000).

The half saturation constants $\left(\mathrm{K}_{\mathrm{s}}\right)$ calculated for the picoplankton are about equal to the $\mathrm{PO}_{4}{ }^{3-}$ concentrations found at those same stations: $0.02 \mu \mathrm{M} \mathrm{PO}_{4}{ }^{3-}$ versus a $\mathrm{K}_{\mathrm{s}}$ of $0.015 \mu \mathrm{M}$ at $\mathrm{Stn} \mathrm{B}, 0.01 \mu \mathrm{M} \mathrm{PO}_{4}{ }^{3-}$ versus a $K_{s}$ of $0.015 \mu \mathrm{M}$ at Stn C. These organisms are therefore very well suited to take up DIP in this area, and are operating near their maximum uptake capacity. Trichodesmium spp., on the other hand, has a $\mathrm{K}_{\mathrm{s}}$ of $0.78 \mu \mathrm{M}$, much greater than the average $\mathrm{PO}_{4}{ }^{3-}$ concentration of $0.04 \mu \mathrm{M}$ observed during our cruise (March 2004). Based on this data and the average $\mathrm{V}_{\max }$, Tricho- 
desmium spp. is operating at 4 to $5 \%$ of maximum $\mathrm{PO}_{4}{ }^{3-}$ uptake capacity at ambient $\mathrm{PO}_{4}{ }^{3-}$ concentrations. Thus, Trichodesmium spp. is poised to take up pulses of high phosphate, should they occur. This finding is similar to that of Suttle et al. (1990), which showed that increasing proportions of DIP enter the larger size fractions as more $\mathrm{P}$ is added to Sargasso Sea water. At a $\mathrm{PO}_{4}{ }^{3-}$ concentration of $0.04 \mu \mathrm{M}$, nearly all of the $\mathrm{PO}_{4}{ }^{3-}(\sim 99 \%)$ is taken up by the picoplankton. However, if $\mathrm{a} \mathrm{PO}_{4}{ }^{3-}$ pulse of $0.4 \mu \mathrm{M}$ were to occur in these waters, about $5 \%$ of the $\mathrm{PO}_{4}{ }^{3-}$ would enter the Trichodesmium spp. pool. At most, $15 \%$ of $\mathrm{PO}_{4}$ could be incorporated into Trichodesmium spp. if $\mathrm{PO}_{4}$ concentrations became high enough. As can be seen, at nominal densities of 1 colony $\mathrm{l}^{-1}$, Trichodesmium spp. will not be a large contributor to $\mathrm{PO}_{4}{ }^{3-}$ uptake even if concentrations increase; however, $\mathrm{PO}_{4}{ }^{3-}$ would become an increasingly important component of total $\mathrm{P}$ acquisition by Trichodesmium spp. Conversely, at more extreme densities of Trichodesmium spp. as are sometimes encountered (Carpenter \& Capone 1992), DIP uptake could be dominated by this phytoplankter.

Using the sum of average $\mathrm{PO}_{4}{ }^{3-}$ uptake and APA, we can calculate the turnover time of Trichodesmium spp. colony P. Assuming a colony P content of $3.9 \mathrm{nmol}$ (Carpenter 1983), the $\mathrm{P}$ turnover time is about $2 \mathrm{~d}$, and doubling time is $1.4 \mathrm{~d}$. This is well within estimates of colony doubling times based on $\mathrm{C}$ or $\mathrm{N}$, which range from 1 to $2 \mathrm{~d}$ to $>1 \mathrm{wk}$ (Carpenter 1983, Carpenter \& Romans 1991). This does, however, assume that all of the DOP pool is bioavailable to Trichodesmium spp. Using the estimate of Björkman \& Karl (2003) of 7 to $15 \%$ DOP bioavailability, turnover of Trichodesmium spp. colony P from DIP and DOP would be 9 to $13.5 \mathrm{~d}$, and a doubling time of 6.2 to $9.4 \mathrm{~d}$. Even when taking the bioavailability of the DOP pool into account, Trichodesmium spp. appears to be able to double its colony $\mathrm{P}$ in about the same amount of time as $\mathrm{C}-$ or $\mathrm{N}$ based estimates of doubling time (Carpenter 1983, Carpenter \& Romans 1991). Thus, Trichodesmium spp. do appear to be able to acquire most or all of the necessary P for growth from the DIP and DOP pools. Slower growth by Trichodesmium spp. or, alternatively, reduced P quotas, would further decrease the doubling times of colony P.

Picoplankton and Trichodesmium spp. both appear to be P-limited or perhaps P-stressed in the subtropical and tropical North Atlantic, and thus the acquisition of $\mathrm{P}$ by these organisms is important to their growth. It appears that each has its own strategy to deal with this problem: picoplankton found in large numbers in bulk water samples have a high affinity for DIP and also the ability to derive some of $\mathrm{P}$ from the organic fraction; in contrast, Trichodesmium spp. cannot compete very successfully for inorganic $\mathrm{PO}_{4}{ }^{3-}$ with smaller organ- isms in the water, but can obtain considerable amounts of $\mathrm{P}$ from the DOP pool. By utilizing this much larger pool, Trichodesmium spp. is able to coexist with picoplanktonic organisms in this area of P limitation.

Acknowledgements. We thank G. Cutter and M. Mulholland for providing berths and shipboard time, and also for providing some of the phosphate data and all the chlorophyll data. We also thank G. Boneillo for running the chlorophyll samples. This work was supported by NSF grants OCE 99-81545 and OCE 99-81371 to DGC and OCE 0136367 to G. Cutter and M. Mulholland.

\section{LITERATURE CITED}

Ammerman JW (1993) Microbial cycling of inorganic and organic phosphorus in the water column. In: Kemp PF, Cole JJ, Sherr BF, Sherr EB (eds) Handbook of methods in aquatic microbial ecology. Lewis Publishers, Boca Raton, FL, p 649-659

Ammerman JW, Hood RR, Case DA, Cotner JB (2003) Phosphorus deficiency in the Atlantic: an emerging paradigm in oceanography. EOS Trans Am Geophys Union 84: $165-170$

Benitez-Nelson CR (2000) The biogeochemical cycling of phosphorus in marine systems. Earth-Sci Rev 51:109-135

Björkman KM, Karl DM (2003) Bioavailability of dissolved organic phosphorus in the euphotic zone at Station ALOHA, North Pacific Subtropical Gyre. Limnol Oceanogr 48:1049-1057

Björkman KM, Thomson-Bulldis AL, Karl DM (2000) Phosphorus dynamics in the North Pacific subtropical gyre. Aquat Microb Ecol 22:185-198

Cañellas M, Agustí S, Duarte CM (2000) Latitudinal variability in phosphate uptake in the Central Atlantic. Mar Ecol Prog Ser 194:283-294

Capone DG, Zehr JP, Paerl HW, Bergman B, Carpenter EJ (1997) Trichodesmium: a globally significant marine cyanobacterium. Science 276:1221-1229

Capone DG, Burns JA, Mahaffey CL, Gunderson T, Michaels AF, Montoya JP, Subramaniam A, Carpenter EJ (2005) Nitrogen fixation by Trichodesmium spp.: an important source of new nitrogen to the tropical and sub-tropical North Atlantic Ocean. Global Biogeochem Cycles 19, doi 10.1029/2004GB002331

Carpenter EJ (1983) Physiology and ecology of marine planktonic Ocillatoria (Trichodesmium). Mar Biol Lett 4:69-85

Carpenter EJ, Capone DG (1992) Nitrogen fixation in Trichodesmium blooms. In: Carpenter EJ, Capone DG, Rueter JG (eds) Marine pelagic cyanobacteria: Trichodesmium and other diazotrophs. Kluwer Academic, Dordrecht, p 211-217

Carpenter EJ, Romans K (1991) Major role of the cyanobacterium Trichodesmium in Nutrient cycling in the North Atlantic Ocean. Science 254:1356-1358

Carpenter EJ, Subramanium A, Capone DG (2004) Biomass and primary productivity of the cyanobacterium, Trichodesmium spp., in the tropical N Atlantic Ocean. Deep-Sea Res I 51:173-203

Codispoti LA (1989) Phosphorus vs. nitrogen limitation of new and export production. In: Berger WH, Smetacek VH, Wefer G (eds) Productivity in the ocean: present and past. John Wiley \& Sons, New York, p 377-394 
Cotner JB, Ammerman JW, Peele ER, Bentzen E (1997) Phosphorus limited bacterioplankton growth in the Sargasso Sea. Aquat Microb Ecol 13:141-149

Donald KM, Joint I, Rees AP, Woodward EMS, Savidge G (2001) Uptake of carbon, nitrogen and phosphorus along the $20^{\circ} \mathrm{W}$ meridian in the NE Atlantic between $57.5^{\circ} \mathrm{N}$ and $37^{\circ} \mathrm{N}$. Deep-Sea Res II 48:873-879

Dyhrman ST, Webb EA, Anderson DM, Moffett JW, Waterbury JB (2002) Cell-specific detection of phosphorus stress in Trichodesmium from the western north Atlantic. Limnol Oceanogr 47: 1832-1836

Dyhrman ST, Chappell PD, Haley ST, Moffett JW, Orchard ED, Waterbury JB, Webb EA (2006) Phosphonate utilization by the globally important marine diazotroph Trichodesmium. Nature 439:68-71

Fu FX, Bell PFR, Hutchins DA (2005) Phosphate uptake and growth kinetics of Trichodemsium (cyanobacteria) isolates from the North Atlantic Ocean and the Great Barrier Reef, Australia. J Phycol 41:62-73

Karl DM, Tien G (1992) MAGIC: A sensitive and precise method for measuring dissolved phosphorus in marine environments. Limnol Oceanogr 37:105-116

Karl DM, Letelier R, Hebel DV, Bird DF, Winn CW (1992) Trichodesmium blooms and new nitrogen in the North Pacific Gyre. In: Carpenter EJ, Capone DG, Rueter JG (eds) Marine pelagic cyanobacteria: Trichodesmium and other diazotrophs. Kluwer Academic, Dordrecht, p 219-237

Krauk JM, Villareal TA, Sohm JA, Montoya JP, Capone DG (2006) Plasticity of $\mathrm{N}: \mathrm{P}$ ratios of laboratory and field populations of Trichodesmium spp. Aquat Microb Ecol 42:243-253

Li WKW, Dickie PM, Irwin BD, Wood AM (1992) Biomass of bacteria, cyanobacteria, prochlorophytes and photosynthetic eukaryotes in the Sargasso Sea. Deep-Sea Res 39: 501-519

McCarthy JJ, Carpenter EJ (1979) Oscillatoria (Trichodesmium) thiebautii (Cyanophyta) in the central North Atlantic Ocean. J Phycol 15:75-82

Michaels A, Karl D, Capone D (2001) Element stoichiometry, new production and nitrogen fixation. Oceanography 14: 68-77

Moutin T, Van Den Broek N, Beker B, Dupouy C, Rimmelin P, Le Bouteiller A (2005) Phosphate availability controls Trichodesmium spp. biomass in the SW Pacific Ocean. Mar Ecol Prog Ser 297:15-21

Editorial responsibility: John Dolan (Contributing Editor), Villefranche-sur-Mer, France
Mulholland MR, Floge S, Carpenter EJ, Capone DG (2002) Phosphorus dynamics in cultures and natural populations of Trichodesmium spp. Mar Ecol Prog Ser 239:45-55

Nausch M, Nausch G, Wasmund N (2004) Phosphorus dynamics during the transition from nitrogen to phosphorus limitation in the celtral Baltic Sea. Mar Ecol Prog Ser 266:15-25

Obernosterer I, Kawasaki N, Benner R (2003) P limitation of respiration in the Sargasso Sea and uncoupling of P-regeneration in size-fractionation experiments. Aquat Microb Ecol 32:229-237

Rivkin RB, Anderson MR (1997) Inorganic nutrient limitation of oceanic bacterioplankton. Limnol Oceanogr 42:730-740

Romans K, Carpenter EJ, B Bergman (1994) Buoyancy regulation in the colonial diazotrophic cyanobacterium Trichodesmium tenue: ultrastructure and storage of carbohydrate, polyphosphate and nitrogen. J Phycol 30:932-934

Sañudo-Wilhelmy SA, Kustka AB, Gobler CJ, Hutchins DA and 6 others (2001) Phosphorous limitation of nitrogen fixation by Trichodesmium in the central Atlantic Ocean. Nature 411:66-69

Sañudo-Wilhelmy SA, Tovar-Sanchez A, Fu FX, Capone DG, Carpenter EJ, Hutchins DA (2004) The impact of surface adsorbed phosphorus on phytoplankton Redfield stoichiometry. Nature 432:897-901

Solorzano L, Sharp JH (1980) Determination of total dissolved phosphorus and particulate phosphorus in natural waters. Limnol Oceanogr 25:754-757

Stihl A, Sommer U, Post AF (2001) Alkaline phosphatase activities among populations of the colony-forming diazotrophic cyanobacterium Trichodesmium spp. (cyanobacteria) in the Red Sea. J Phycol 37:310-317

Suttle CA, Fuhrman JA, Capone DG (1990) Rapid ammonium cycling and concentration-dependent partitioning of ammonium and phosphate: implications for carbon transfer in planktonic communities. Limnol Oceanogr 35:424-433

Thingstad TF, Krom MD, Mantoura RFC, Flaten GAF and 15 others (2005) Nature of phosphorus limitation in the ultraoligotrophic Eastern Mediterranean. Science 309: 1068-1071

Tyrell T (1999) The relative influences of nitrogen and phosphorus on oceanic primary production. Nature 400:525-531

Wu J, Sunda W, Boyle E, Karl D (2000) Phosphate depletion in the western North Atlantic Ocean. Science 289:759-762

Wu J, Boyle E, Sunda W, Wen L (2001) Soluble and colloidal iron in the oligotrophic North Atlantic and North Pacific. Science 293:847-849

Submitted: September 23, 2005; Accepted: December 16, 2005 Proofs received from author(s): June 23, 2006 